\title{
An Exploratory Study to Identify the Impact of Leadership Styles on Achieving Institutional Excellence in the Public Sector: United Arab Emirates
}

\author{
Asaad Ali Karam ${ }^{1} \&$ Abdelkarim Fuad Kitana ${ }^{2}$ \\ ${ }^{1}$ Assistant Professor, Human Resource Management Department, UAE \\ ${ }^{2}$ City University College of Ajman, Ajman, UAE \\ Correspondence: Dr. Asaad Ali Karam, HRM Department, City University College of Ajman, Sheikh Ammar \\ Road, Ajman, United Arab Emirates. E-mail: asaad.ali@uod.ac / a.karam@cuca.a
}

Received: March 20, 2020

doi:10.5539/ijbm.v15n6p16

\author{
Accepted: April 23, 2020 \\ Online Published: May 10, 2020 \\ URL: https://doi.org/10.5539/ijbm.v15n6p16
}

\begin{abstract}
The main purpose of the study was exploratory the influence of leadership styles (LS) on institutional excellence (IE) to find out the best indicators for developing the UAE leadership, and achieving (IE). In the modern era, the leadership styles in organizations are facing several challenges due to the dynamic nature of the environment. The research questions seek to uncover (a) appropriate leadership styles within successful organizations, and (b) what, if any, the role exists between leadership styles and measures of success on (IE). The aim of this study was to find out the most suitable leadership styles in the public sector to achieve better institutional excellence. The study employed a quantitative approach; data were collected through a self-administered questionnaire consist of (49) items. Convenience sampling was used to collect data from (329). The results indicate a positive effect between Transformational model (LS) and (IE) with $\left(\mathrm{R}=0.845 / \mathrm{R}^{2}=0.714 / \mathrm{sig} .=0.00\right)$. However, findings indicate that leadership expects to: enter the profession prepared to fulfill the requirement of the position, have the ability to make a difference, and be provided with support from their organization. Findings the most stabile leadership styles in UAE organizations were both transformational and transactional leadership with majority respondents statistically significant and all hypotheses supported the seven leadership styles on institutional excellence. The study concludes with some brief prospects that the organization needs to realize the importance of leadership styles for maximizing the level of institutional excellence. This research may benefit society by encouraging people to contribute more to their jobs and may help them in the organization's growth and development.
\end{abstract}

Keywords: leadership styles, institutional excellence, vision, transformational leadership

\section{Introduction}

Institutions live in a changing environment, characterized with a high degree of complexity, and perform their services in an environment characterized as challenges, economic openness, pressures, and influencing forces of change represented by external elements including leaders economic, political, technological, social, and internal forces such as: changing the goals of the institution, values and trends, organizational climate, individuals and methods of work were the main factor in stimulating institutions and pushing them towards activating excellence (Naser \& Al Shobaki 2017). Organizations and institutions of all kinds and different specializations need a conscious, responsible and influential leadership model in individuals and groups that are responsible for moving the human cadre to keep pace with all progress and development in the environment (Taamneh et al., 2018). The researcher has seen the institutions 'interest in leaders at all levels and we have seen the organizations endeavor to develop their leadership skills, so the leader is the most important component in any gathering. The pursuit of applying excellence in any institution is a basic requirement in light of the environmental changes taking place in the current situation in the Emirates, which requires these institutions to adopt an administrative philosophy that helps them to overcome difficulties and create superiority and development in performance to reach the ability to survive and compete in an environment where methods and strategies are transformed and evolving technology, services become obsolete, and processes change rapidly (Christensen et al., 2020).

Thus, the researchers find that the study of leadership styles is necessity of administrative development 
imperatives to raise levels of performance through the availability of several components, the most important of which are: the availability of an effective leadership style, the existence of an integrated system of policies that govern and organize the work of the institution through a leadership style, flexible organizational structures, an advanced quality system, system An advanced human resource development, an advanced information system, and effective leadership that sets the foundations and standards for implementing plans, policies, and decision-making, developing the skills and capabilities of workers, in order to achieve enterprise excellence and success (Chaluvadi, 2015).

The achievement of institutional excellence in all its standards and indicators is based on strategic planning in building a sound and solid foundation for all its components, which are policy planning, systems, structure development, process planning, investment of resources, and the development of human and material capabilities in order to achieve the goals of the institution, and gives it the ability to conduct an organizational analysis Institutional and regularly updated, with the aim of creating an appropriate leadership style in order to manage continuous improvement and improvement (Tempel et al., 2016). Therefore, the appropriate leadership style should be characterized by vitality, flexibility, renewal, and openness, and focus on vision, mission, goals, policies, procedures, and conduct an in-depth strategic analysis of an inner and outer conditions to recognize advantages, weaknesses, chances, and threats in preparation for formulating the appropriate strategies that ensure achieving excellence in performance and enhancing competitiveness. Given the importance and vitality of this issue in the current reality of government organizations in the United Arab Emirates, and the results of competition between government institutions to provide the best services to clients, so the role of the strategic leader in achieving institutional excellence is of great importance by contributing to improving its performance and helping it achieve its mission and goals.

\subsection{The Objective of Study}

This paper aims to demonstrate the importance of leadership styles on institutional excellence in promoting sustainable development efforts through:

1. Standing on the main concepts of leadership styles, institutional excellence, and strategies that need to be followed by government organizations to reach an effective contribution when implementing sustainable development plans and satisfying auditors in institutions.

2. Presenting the proposals that ensure the development of institutions as a starting point for the promotion and support of sustainable development efforts in order to activate their role in a way that benefits society as a whole.

3. Highlighting the role of appropriate leadership styles in the institutional excellence of the government sector.

\subsection{The Problems of Study}

The Ministry of the Interior is considered in the United Arab Emirates or in any of the ministries that have the privacy that distinguishes it from other government institutions and others in view of the functional tasks assigned to organizations and employees in this ministry.

However, relying on the theoretical literature and previous studies that dealt with the influence between leadership styles practices and institutional excellence, it was found that there is a difference in the results of those studies, and this is confirmed by previous studies where one of these studies confirmed the existence of a relationship between external sources of employment, performance and excellence organizational through leadership patterns, hence the current research came to clarify the gap in previous studies and research that relate to the role that leadership styles practices can play in institutional excellence in the government sector, as well as identifying work problems and performance gaps, identifying and analyzing internal and external customer requirements for organizations, and setting standards to improve business procedures through leadership styles.

\subsection{The Question of Study}

From the results of previous studies, it is possible to define the following main question:

Does there an impact of leadership styles on institutional excellence in government organizations?

The above main question is divided into the following questions:

1. How can different institutions choose the appropriate leadership styles in achieving institutional excellence?

2. Is there an impact of leadership styles on institutional excellence in the government sector?

3. Is there an impact of leadership styles on organizational excellence through innovation, empowerment, and vision realization? 


\section{Literature Review and Hypotheses Development}

Leadership is one of the most important topics in society, because of its prominent and important role in the progress of organizations (Antonakis, 2017). Leadership has become an essential element to rationalize the behavior of individuals and mobilize their energies towards achieving institutional excellence (Aithal, 2015). The researcher aims through this branch to address some of the study literature related to the topic of research, starting with learning about the concept of leadership and its importance as well as identifying leadership theories and leadership patterns, and the importance of this branch lies in providing the researcher with various basic concepts and principles related to the topic of the study and helping to build the study tool, and interpretation of the results. Therefore the following hypothesis has been suggested in order to explain the main hypothesis:

H1: There is a significant effect among leadership styles with institutional excellence (Innovation, Enablers, and Vision) at the function level (Alpha> 0.05).

\subsection{Definition of Leadership}

Despite the interest of many scholars, writers and philosophers in studying the issue of leadership, there is no agreement on a unified definition of this concept, due to the multiplicity of schools that dealt with this concept, hence, the researcher will present the most important definitions that were received, with the aim of reaching a general concept of leadership

The leader defined that he is the individual who can influence others or who drives the group to achieve certain goals (Bekker, 2015).

Jian \& Fairhurst (2017), define leadership as "the ability to make an impact on people by contacting them and directing them toward achieving one of the goals."

\subsection{The Importance of Leadership}

The large and large organizations have led to interest in leadership and made the leader responsible for caring for human relations, and for developing communication with the largest possible number of workers so that this process continues and accomplishes its objectives and achieves its goals, making management more dynamic and effective, and it works as a driving tool for it to achieve its goals (Overall, 2015).

\subsubsection{The Leader's Strengths}

Leadership is embodied in a person who has a leadership position through which he can exert influence on a group of individuals in a specific situation, and for a leader to be successful and able to actually influence his followers; he must have certain powers (Gentry et al., 2016). Accordingly, the sources of leadership power are classified as follows:

First: The Official Authority

The most prominent of which are the following:

1- Reward force

When an individual feels that his obedience to his boss's orders will return to him with a material reward (salary, wage, for example), or a moral reward (a letter of gratitude and appreciation, a work medal, etc.), he will look at his boss as a leader and respect this characteristic in him, in this case, the source of the driving force is The reward strength the leader gives to his subordinates (Smith et al., 2016).

\section{2- The power of coercion}

When the individual feels that his failures in his work will lead to deprivation of the reward, or will result in a deterrent punishment imposed on him, whether the punishment is material or moral, then the fear here will belong to the individual, so we say in this case that the source of strength is the fear of the president if the individual committed An act punishable (Valeriano et al., 2018).

3- The legal authority

The source of this power is the official center that the individual has occupied in the administrative organization, and this power flows from top to bottom (Wildavsky, 2018).

Second: Strength of Impact

This strength is related to the person himself and not to the position. Among the most prominent forms are the following: 


\section{1- Power of expertise}

The accumulated experience in the field of specialization or knowledge that the individual possesses and which is distinct from that of others or his peers, gives him the strength to be able to lead, as the ancient chemical engineer in his specialty and expert in his field of work. He has the power to specialize in influencing other engineers who do not possess this unique strength from subtle specialization and broad and in-depth knowledge in the field of chemical engineering, and so on (Fletcher, 2017).

\section{2- The power of admiration}

The individual usually obtains it as a result of his followers' admiration of some personal qualities that make them relate to him, and they express their admiration for him and their appreciation for him because gravity makes this individual a leader that affects others (Karkoulian, 2015).

\subsubsection{The Great Man Theory}

This theory is summed up in the fact that the unique characteristics that a person enjoys exclusively without other members of his group are imposed by a leader on them, and this theory assumes that the changes that occur in the life of the group, but are achieved by people who have unusual talents and abilities (Mouton, 2019). Thus, it becomes clear to the researcher that this theory believes that leaders are exceptional people born with great talents and inherited traits that make them leaders, and the researcher believes that this theory failed to explain the phenomenon of leadership and characterization of the leader, so it cannot be relied upon in many situations to determine the true leader.

\subsection{Leadership Styles}

Leadership styles differ from one leader to another, each leader has own style of influencing subordinates in order to achieve the goals of the institution, and often this style determines the philosophy of leaders themselves, their personalities, and experiences (Anderson \& Sun 2017). The researchers will explain each type of (LS) which are used in the current study, respectively:

\section{Autocratic}

Autocratic pioneers are great "do as I say" types. Commonly, these pioneers are fresh with a specialist push onto them as another position or errand that incorporates a person's organization. Totalitarian pioneers can hurt an affiliation unsalvageable as they drive their 'followers' to execute methods and organizations in an uncommonly confine course from the perspective of a subjective idea of what accomplishment looks like (Fiaz \& Saqib 2017). Hence, the following hypothesis was formulated:

H1a: There is a significant effect of an Autocratic style on institutional excellence (Innovation, Enablers, and Vision) at the function level (Alpha $>0.05)$.

\section{Bureaucratic}

Bureaucratic pioneers are most content with relying upon a communicated approach in order to influence disciples to get on board. In doing accordingly they send a prompt message that methodology oversees course. Bureaucratic pioneers are commonly insistently committed to technique and methods instead of people, and hence, they may appear to be saved and extremely change troublesome. The danger here is that activity's most unmistakable points of interest, motivating and making people are slighted by bureaucratic pioneers (Cunningham et al., 2015). Further, the below hypothesis was proposed:

$H 1 b$ : There is a significant effect of Bureaucratic style on institutional excellence (Innovation, Enablers, and Vision) at the function level (Alpha $>0.05$ ).

\section{Democratic}

Democratic pioneers are baffled by the tremendous exertion required to gather understanding for even the most unremarkable choices and what increasingly the icy is pace required to lead a social affair by fiat. The potential for poor crucial specialist and powerless execution is huge here. The most troublesome issue with Democratic movement is its basic suppositions that everybody has an indistinguishable stake in a result and moreover presented levels of twisted to respect to choices (Gandolfi \& Stone, 2017). However, the following hypothesis was offered:

H1c: There is a significant effect of Democratic style on institutional excellence (Innovation, Enablers, and Vision) at the function level (Alpha $>0.05$ ). 


\section{Charismatic}

Charismatic pioneers have a dream, an identity that rouses supporters to execute that vision. Consequently, this writing from the administration was usually one of the most appreciated. Magnetic administration gives creativity and creation of productive ground and is also highly motivational. Further, with magnetic pioneers in charge, the affiliation's people fundamentally need to take after. It sounds like the most perfect circumstance. There is, regardless, one critical issue that conceivably undermines the estimation of appealing pioneers: they can get out (Al Khajeh, 2018). Hence, the next hypothesis has been developed:

H1d: There is a significant effect of Charismatic style on institutional excellence (Innovation, Enablers, and Vision) at the function level (Alpha> 0.05).

\section{Situational}

Situational administration speculation recommends that the best pioneers incessantly change by getting a handle on arranged styles for various conditions or results. This hypothesis mirrors a humbly complex perspective of movement in every practical sense and can be an advantageous bundling of reference for experienced, organized pioneers who are especially mindful of the honest to goodness need and individual inspiration. Above all, it gifts experienced pioneers the opportunity to examine a blend of authority cycles (Tortorella \& Fogliatto 2017). Thus, the following hypothesis has been conceived:

H1e: There is a significant effect of Situational style on institutional excellence (Innovation, Enablers, and Vision) at the function level (Alpha $>0.05)$.

\section{Transactional}

The wheeler-traders of activity styles, esteem based pioneers are persistently prepared to give something as a final product of following them. In case the incentive to do it is the key factor, what happens in the middle of a lean situation when resources are thinly stretched and a game plan is not possible? Everything considered, esteem based pioneers as a less than dependable rule demonstrate the attributes or practices of enchanting pioneers and can be exceptionally fruitful all things considered while making impelled players (Holten \& Brenner 2015). The following hypothesis has been incorporated for the present study:

H1f: There is a significant effect of Transactional style on institutional excellence (Innovation, Enablers, and Vision) at the function level (Alpha> 0.05).

\section{Transformational}

Transformational pioneers want to change those they lead in doing as needs are, they can address sensible, self-rehashing movement (Elrehail et al., 2018). Not substance to just utilize the vitality of identity (appealing) or overseeing (regard based) to affect sweethearts, transformational pioneers utilize learning, predominance and vision to change everyone around them. Transformational pioneers tackle the most basic kind of Leader, as supporters will improve, and become sponsors. (Yahaya \& Ebrahim 2016; Kitana, 2019). Moreover, the following hypothesis has been produced:

H1h: There is a significant effect of the Transformational style on institutional excellence (Innovation, Enablers, and Vision) at the function level (Alpha>0.05).

\subsection{Institutional Excellence}

A state of excellence in an efficient and effective offering all services across processes ensure continuous improvement in all areas and at all levels and strive to sustain this distinction by maintaining continuous pace with growth. The institutional excellence was defined as "a state of administrative creativity, organizational excellence that achieves extraordinary levels of performance in the organization (Kok \& McDonald 2017; Sendjaya, 2016). The researcher defines institutional excellence (IE): as a case of creativity and administrative or organizational excellence and the achievement of high and unusual levels of performance, which results in results and achievements and outperforms what the competing organizations achieve, and the customers and all stakeholders in the organization satisfy them.

\subsubsection{Institutional Excellence Principles}

There are a set of basic principles of organizational excellence as per Mohamed, et al., (2018), among which mention:

1. The principle of leadership democracy: It means breaking out of the traditional bureaucratic patterns, expanding the circle of decision-making, and caring for informal communications to achieve more effectiveness.

2. The principle of variability: It means having a healthy climate, positive attitudes and sufficient culture while 
stimulating positive constructive competition.

3. The principle of independence: It is the technical, administrative and financial independence in order to set the distinction and take what it deems appropriate for excellence and continuity, as it means adopting the decentralized and semi-independent administrative approach to departments and opening the way to create competition between departments and departments with close monitoring of the prevailing work systems.

4. The principle of approaching customers: by providing distinguished service with good quality and ensuring product quality.

5. The principle of productivity: it means focusing attention on the mechanisms and procedures for achieving high-quality outputs and within the approved international standards.

6. The principle of Innovation: It means creating creative, permanent ways for continuous improvement and improvement.

\subsubsection{Institutional Excellence Dimensions}

It executes the key tasks effectively and efficiently, ensuring that its priorities and the objectives of the Government as a whole are met, utilizing resources optimally and actively pursuing learning and growth (Al Shobaki \& Abu-Naser 2016). The following is a detailed explanation of the three axes:

1. Innovation

The leading government agency endeavors to continuously innovate in its work by leading transformational thinking, providing new and innovative services, developing its policies and implementing its operations and programs in innovative ways in a manner that ensures the achievement of the principles of economic, social and environmental sustainability in the long term (Carayannis et al., 2017; Elrehail, 2018).

\section{Enablers}

The leading government institution offers its services and executes its programs by managing facilities and resources effectively and efficiently to ensure adherence to the highest levels of transparency, fairness, leadership and efficient management of strategic and operational risks and strategic coordination with each stakeholder (Agarwal \& Vrat 2015; Kitana \& Karam 2017).

\section{Achieve the vision}

The pioneering government agency achieves the goals entrusted to it within the framework of the national agenda, its strategic plan, and its main tasks through design and effective and efficient application of its operations, services, programs and projects and working on a smart transformation of its services and operations in a manner that ensures meeting and exceeding the expectations and requirements of all stakeholders, partners, and society in a manner that achieves the highest levels of satisfaction and happiness (Sendjaya, 2016).

\subsection{The Five Stages of an Organizational Excellence}

First stage: It is the stage in which a team is formed within the organization to lead the quality of performance and develop institutional performance in it, and this team must carry out the necessary awareness-raising processes for the importance of achieving excellence and quality in performance and it must build a culture supportive of institutional development (Naser \& Al Shobaki 2017; Karam, 2019).

Second stage: It is the stage of self-evaluation of the institution, there is no doubt that this step and that stage is the most important and most dangerous towards achieving excellence and the desired quality of performance within the institutions (Muralidharan, 2015; Ahn et al., 2018).

Third stage: It is the stage of setting the priorities for institutional development, and this stage comes after the self-evaluation phase, in which the strengths in institutional performance, and the aspects that need to be developed and improved, are defined, and at this stage, the performance gaps that most adversely affect the productivity of the organization and achieve its goals are determined according to its vision and mission (Lewis et al., 2015).

Fourth stage: It is the stage of designing and preparing the procedural plan for the development of institutional performance, and here the work team that is able to build such plans is formed, determining the necessary schedule for the management and implementation of this plan (Amit et al., 2015).

Fifth stage: It is the stage of monitoring and evaluating the performance associated with the implementation of the procedural plan to develop institutional performance, and here a team is formed to follow-up and evaluate performance (Jundt et al., 2015). 
According to Hassan, A. (2010), a study entitled "human resources management practices and their impact on achieving institutional excellence", this work aimed at defining the effect of activities in the management of human resources. The researcher designed a questionnaire that included (40) items to collect data, and the study sample consisting of (253) respondents. Among the most prominent of its results is the presence of significant leadership in achieving organizational excellence through HRM activities (Karam \& Kitana 2018). A study aimed to get acquainted with the concept of human resources management and its importance in achieving institutional excellence. Among the most prominent results obtained are: 1. The Company relies on highly qualified and experienced workers to occupy important jobs. 2. Senior management adopts strategic goals based on clients' needs and desires. 3. The leaders are keen to give their subordinates the powers that contribute to performing the work (Ali, 2012).

As per Pinar \& Girard (2008) examined the effect of institutional Excellence and Leadership on Performance. The research randomly drew a sample of (200) companies out of (7200) firms in the three cities. The findings of this study were that the leadership support through vision as one of Institutional Excellence measurement and have a significant influence on performance. Sahoo \& Sahu (2009), effective employee engagement: the mantra of achieving organizational excellence, they mentioned that in many high-tech and service industries, businesses not only concentrate on ways and recruit the right workers, but also on ways of retaining the right employees and ensuring their happiness and productivity (Kitana \& Karam 2019; Taamneh, 2015).

\section{Methodology and Procedures Design}

The present study was designed to comprehend the effect that exists between leadership styles and institutional excellence, through independent variables: (7) leadership styles, and dependent variables through innovation, enablers, and achieve the vision. The self-designed questionnaire was outlined in one of the models that were accessible on "https://www.surveygizmo.com." The questionnaire was progressed in two sections for managers and employees. The reason to choose the quantitative approach for this study was to apply numerical and computational strategies to determine an outcome (Weber, 2017). The research relied on the federal government through the ministry of Interior, by some of the public organizations in the UAE, (5) executive leaders were chosen from all institutions of the Ministry of Interior with an unlimited number of employees in each institution. Thus, the data collection technique method was convenience sampling. The explanation behind such a decision was to understand how leadership styles and directors select the suitable style of leadership relying upon achieving institutional excellence.

Therefore, to determine the required sample size the study depends on the following information the Confidence Level: (95\%), Confidence Interval (5), Population (5000), and needed Sample Size (357) which has been distributed on www.surveysystem.com. Hence, the (329) responders were completely received which means $(92 \%)$ of the questionnaire has been achieved. The research relies on the descriptive and analytical approach in order to discover the appropriate leadership styles in the institutions in order to achieve institutional excellence. The data accumulated from surveys were investigated by "Statistical Package for Social Sciences" (SPSS) Version 22.0 (Kumar, 2019).

\subsection{The Study Model}

A calculated model is a representation of a system that uses ideas and thoughts to form the representation. By using a theoretical model to detect the ideas of the sample, the concept of an idea versus a measured concept is important to consider. The theoretical models are also used as a single representation of true questions (Bottoni, 2018). A measured model will typically fulfill four main objectives:

1. Improve the delegate framework's comprehension.

2. Encourage competent transport between colleagues of the subtle structure elements.

3. Offer the originators a perspective in order to assemble specifics of the structure.

4. Register the future benchmark system.

The effectiveness model of (LS) on (IE) in UAE can be illustrated as a (Figure 1), as shown below.

\section{Data Analysis and Results}

\subsection{Descriptive Statistics}

Descriptive statistics are short undisputed coefficients that accumulate a specific instructional list, either as a reflection of the entire population or as a case of it (Gray, 2019). The present study depends on the following descriptive elements: Gender, Age, Marital Status, and Education Level. Thus, the results indicated for (Gender) $(30.8 \%)$ of selected employees and managers at UAE are female, while the extents of the male are $(69.2 \%)$, in 
the event that studies contrast survey findings, this rate is higher than the female. Since, the results show (age) variety for (7) age groups (26-35 years of age) and the highest recurrence of (142\%) (43.2\%) the assessment indicates that a very youthful job drive is valued. While, the highest proportion of workers who are single $(58.7 \%)$ and who are married $(41.3 \%)$ as seen in the results for (marital status). Moreover, (Education Level) obviously demonstrates the distinction in the instructive level of the members of the study. As results demonstrate work drive holding a four-year certification this shows most of the work compel populace in this investigation holds college degrees with (53.5\%) percentage.

\subsection{Reliability of Study}

Table 1 . Summary of reliability statistics

\begin{tabular}{ll}
\hline “Cronbach's Alpha” (0.933) & N of Items (49) \\
\hline Cases-Valid (N=323) & $98.2 \%$ \\
Excluded $\left.^{\text {a }} 6\right)$ & $1.8 \%$ \\
Total (329) & 100.0 \\
\hline
\end{tabular}

Note. a. Listwise deletion based on all variables in the procedure.

The reliability level tests were conducted to evaluate the reliability and degree of lucidity within each factor between components with a basic estimate of (0.6) the estimation of "Cronbach's Alpha" was commendable (Cypress, 2017). In order to find out the evaluation of "Cronbach's Alpha" with (49) items and (329) respondents that will make the unfavorable output of an investigation more evident, the general outlook on Cronbach's alpha was used to evaluate all variable alpha, and (Table 1$)$ showed the estimate of $(0,933)$ mean that the rating was higher than an estimate $(0,6)$. That could serve as a rationale for the reality of the questionnaire because the Cronbach Alpha calculation was considered remarkably reliable for investigation.

\subsubsection{Validity of Study}

Table 2. KMO and Bartlett's test

\begin{tabular}{lll}
\hline \multicolumn{2}{l}{ "Kaiser-Meyer-Olkin Measure of Sampling Adequacy". } & .848 \\
\hline & "Approx. Chi-Square" & 2678.323 \\
"Bartlett's Test of Sphericity" & df & 45 \\
& Sig. & .000 \\
\hline
\end{tabular}

The KMO obliged inspecting adequacy with the esteem greater than (0.5) for an attractive result to stack on additionally factor examination. "KMO and Bartlett's test" were used to show the power of the connection through factors. "Bartlett's test" was another basic sign demonstrate the power of the connection into elements (Cypress, 2017). As the consequence of "KMO and Bartlett's" trial of research factors through (49) inquiries without statistic factors, the KMO was (0.848) it pointed that the sufficiency of examining was tasteful. Thusly, "Bartlett's Test of Sphericity" result demonstrates the level of hugeness was $(0.00)$ and littler than $(0.05)$ (Karam et al., 2018).

\subsection{Multiple Linear Regression Analysis}

Multiple regressions for determining the consequences connections of the variable include seeking to explain the functions of the dependent variables (Y) and independent ones (X) (Karam \& Saydam 2015). For example, a regression of seven leadership styles on the organization's excellence, it would probably see a significant relationship and the most effective styles. When the purpose of multiple regressions understands functional relationships as mentioned by Silhavy et al., (2017), the important result is an equation containing standard partial regression coefficients, like this:

$$
\mathrm{y}^{\mathrm{r}}=a+b_{1}^{\prime} x_{1}^{\prime}+b_{2}^{\prime} x_{2}^{\prime}+b_{3}^{\prime} x_{3}^{\prime} \ldots
$$

Ultimately, " $(\mathrm{Y}=\mathrm{bX}+\mathrm{a})$; (Y) Predicted value of $\mathrm{Y}$. (bX) Slope = rate of increase / decrease of $\mathrm{Y}$ hat for each unit increase in $\mathrm{X}$, (a) Y- Intercept $=$ level of $\mathrm{Y}$ when $\mathrm{X}$ is 0 ". 
Table 3. Model summary all variable together

\begin{tabular}{|c|c|c|c|c|c|c|c|c|c|}
\hline \multirow[b]{2}{*}{ M } & \multirow[b]{2}{*}{$\mathrm{R}$} & \multirow[b]{2}{*}{$\mathrm{R}^{2}$} & \multirow[b]{2}{*}{ A. $\mathrm{R}^{2}$} & \multirow[b]{2}{*}{ Std. Er. } & \multicolumn{5}{|c|}{ Change Statistics } \\
\hline & & & & & $\mathrm{R}^{2} \mathrm{Ch}$. & F Ch. & df1 & df2 & Sig. F Ch. \\
\hline 1 & $.747^{\mathrm{a}}$ & .558 & .557 & .595 & .558 & 410.259 & 1 & 325 & .000 \\
\hline 2 & $.787^{\mathrm{b}}$ & .620 & .617 & .553 & .062 & 52.696 & 1 & 324 & .000 \\
\hline 3 & $.792^{\mathrm{c}}$ & .627 & .624 & .548 & .007 & 6.473 & 1 & 323 & .011 \\
\hline 4 & $.797^{\mathrm{d}}$ & .635 & .630 & .543 & .008 & 6.812 & 1 & 322 & .009 \\
\hline 5 & $.821^{\mathrm{e}}$ & .674 & .669 & .514 & .039 & 38.576 & 1 & 321 & .000 \\
\hline 6 & $.844^{\mathrm{f}}$ & .712 & .707 & .484 & .038 & 42.548 & 1 & 320 & .000 \\
\hline 7 & $.845^{\mathrm{g}}$ & .714 & .708 & .483 & .001 & 1.612 & 1 & 319 & .205 \\
\hline
\end{tabular}

Notes. a. Predictors: (Constant), Autocratic.

b. Predictors: (Constant), Autocratic, Bureaucratic.

c. Predictors: (Constant), Autocratic, Bureaucratic, Democratic.

d. Predictors: (Constant), Autocratic, Bureaucratic, Democratic, Charismatic.

e. Predictors: (Constant), Autocratic, Bureaucratic, Democratic, Charismatic, Situational.

f. Predictors: (Constant), Autocratic, Bureaucratic, Democratic, Charismatic, Situational, Transactional.

g. Predictors: (Constant), Autocratic, Bureaucratic, Democratic, Charismatic, Situational, Transactional, Transformational.

From the table (3), it has been demonstrated the quality of the connection between autonomous factors Autocratic (X1), Bureaucratic (X2), Democratic (X3), Charismatic (X4), Situational (X5), Transactional (X6), and Transformational Leadership Styles (X7) value, confidence, and the Institutional Excellence (Y) subordinate variable was reflected by R-esteem. The R-square has demonstrated the relapse show execution. The most grounded esteem was the profitability of the entire model. While, the R-Square esteem has demonstrated the (7) autonomous factors were firmly influencing on the institutional excellence subordinate variable. Thusly, it has been demonstrated that the R-Square coefficient of assurance was showed up respectively $(0.558),(0.620)$, (0.627), (0.635), (0.674), (0.712) and (0.714), while the strongest impact was Transformational style of leadership this could be the finding that the leaders in UAE most of them are Transformational for present case. As consequences of investigation, Transformational style has came with $(\mathrm{R}=0.845)$ which demonstrates a sensible positive connection with $\left(\mathrm{R}^{2}=0.714\right)$ demonstrates the free factors clarify $(70.8 \%)$ of the fluctuation in appropriation. It implies around $(70.8 \%)$ of the variety in institutional excellence can be depicted by the variety in model (g) predictors (Onsardi \& Arkat 2020).

\subsubsection{ANOVA of Study Factors}

Table 4. ANOVA

\begin{tabular}{llllll}
\hline $\mathrm{M}$ & Sum of Squares & df & Mean Square & F & Sig. \\
\hline Regression & 185.705 & 7 & 26.529 & 113.684 & $.000^{\mathrm{a}}$ \\
1 Residual & 74.442 & 319 & .233 & & \\
$\quad$ Total & 260.147 & 326 & & & \\
\hline
\end{tabular}

Notes. a. Predictors: (Constant), Autocratic, Bureaucratic, Democratic, Charismatic, Situational, Transactional, Transformational

b. Dependent Variable: Institutional excellence

From (Table 4), ANOVA test demonstrates the acknowledgment of institutional excellence on autonomous factors are factually huge, while, the "F-value is measurably huge", $F=113.684$, with the p-value was littler than $(0.05)$ (Sig. $=0)$ which implies that no less than one of the seven indicator factors can be utilized to show Institutional excellence (Kim, 2017; AbduRazak et al., 2019). 


\subsubsection{Coefficients of Study Factors}

Table 5. Coefficients ${ }^{\mathrm{a}}$

\begin{tabular}{|c|c|c|c|c|c|c|}
\hline & \multirow{2}{*}{ M } & \multicolumn{2}{|c|}{ Un-s-Coefficients } & \multirow{2}{*}{$\frac{\text { S-Coefficients }}{B}$} & \multirow{2}{*}{$\mathrm{t}$} & \multirow{2}{*}{ Sig. } \\
\hline & & $B$ & S-Error & & & \\
\hline \multirow{8}{*}{1} & (Constant) & .575 & .146 & & 3.944 & .000 \\
\hline & Autocratic & 1.080 & .088 & 1.131 & 12.213 & .000 \\
\hline & Bureaucratic & .390 & .054 & .380 & 7.224 & .000 \\
\hline & Democratic & $-.088-$ & .034 & $-.107-$ & $-2.552-$ & .011 \\
\hline & Charismatic & .165 & .047 & .146 & 3.491 & .001 \\
\hline & Situational & $-.300-$ & .035 & $-.455-$ & $-8.488-$ & .000 \\
\hline & Transactional & $-.273-$ & .041 & $-.361-$ & $-6.607-$ & .000 \\
\hline & Transformational & $-.062-$ & .049 & $-.067-$ & -1.269 & .205 \\
\hline
\end{tabular}

Note. a. Dependent Variable: Institutional excellence.

The test coefficients according to (Table 5), through the multiple regression models, were used to find the most efficacious independent variables, hence, the highest s-coefficient (Beta) was matched by (Autocratic style) which was $(B=1.131)$, t-statistic (12.213), and significant p-value was $(0.00)$ in a separate measurement. While, the transformational styles has the lowest (s-coefficient) with (-0.067-) with (-1.269) t-statistic, and (0.205), non-significance p-value. It illustrates that one "standard deviation" increase in autocratic is followed by $(0.088)$ s-coefficient beta increases in (Institutional excellence). It can be explained by other independent variables in the same way. This model can, therefore, be used for the purpose of estimation (Zhang, 2017; Sleimi, et al., 2018).

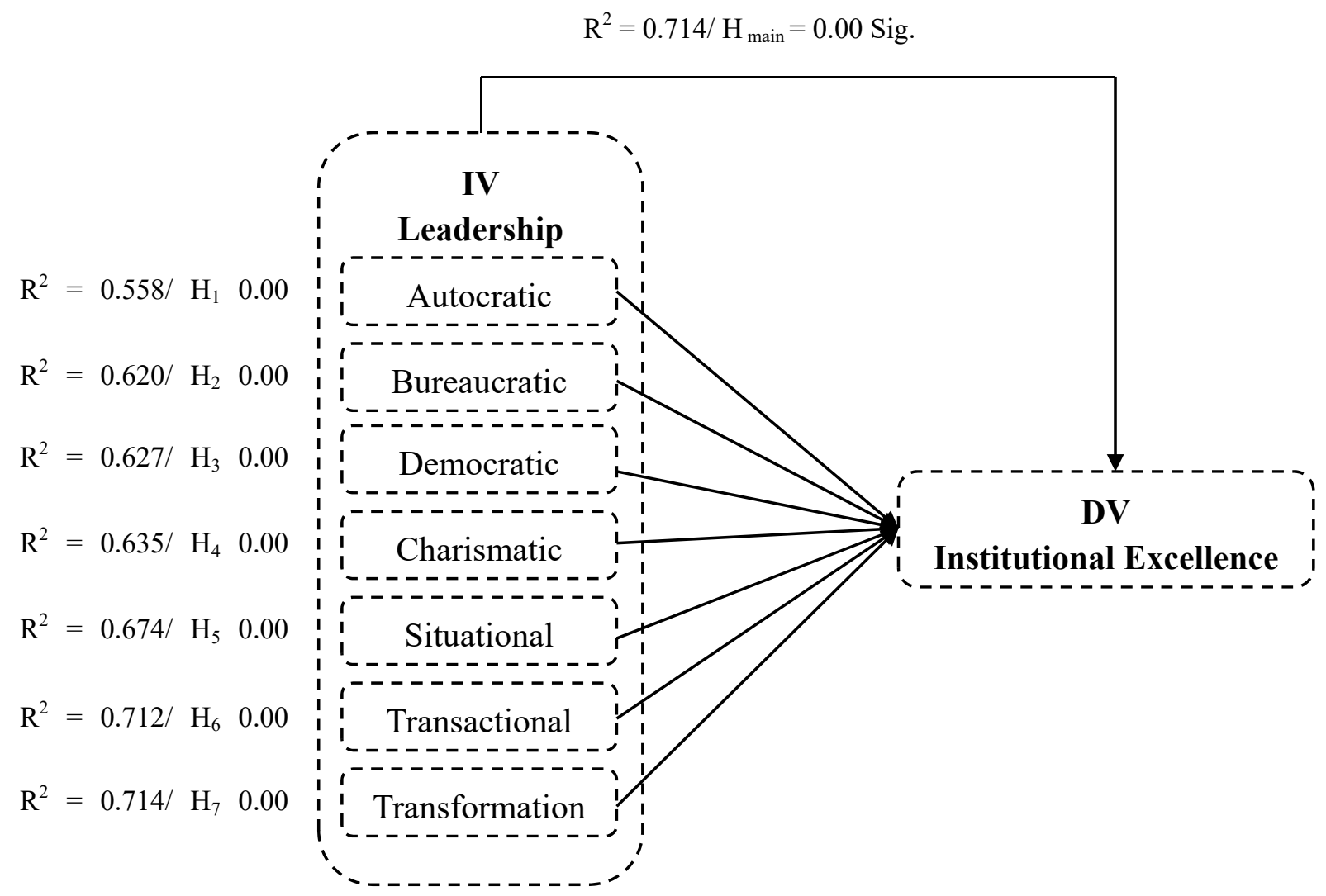

Figure1. Summary conceptual model 


\subsection{Hypothesis Testing}

Table 6. One-Sample test

\begin{tabular}{|c|c|c|c|c|c|c|}
\hline & \multicolumn{4}{|c|}{ Test Value $=0$} & \multicolumn{2}{|c|}{$95 \% \mathrm{CI}$} \\
\hline & $\mathrm{t}$ & $\mathrm{df}$ & Sig. (2-t) & MD & $\mathrm{L}$ & $\mathrm{U}$ \\
\hline $\mathrm{IE}$ & 77.160 & 328 & .000 & 3.696 & 3.60 & 3.79 \\
\hline Autocratic & 74.309 & 328 & .000 & 3.837 & 3.73 & 3.93 \\
\hline Bureaucratic & 81.855 & 328 & .000 & 3.922 & 3.82 & 4.01 \\
\hline Democratic & 63.876 & 328 & .000 & 3.829 & 3.71 & 3.94 \\
\hline Charismatic & 86.241 & 328 & .000 & 3.766 & 3.68 & 3.85 \\
\hline Situational & 46.138 & 328 & .000 & 3.444 & 3.30 & 3.59 \\
\hline Transactional & 58.780 & 327 & .000 & 3.823 & 3.70 & 3.95 \\
\hline Transformational & 72.905 & 328 & .000 & 3.891 & 3.78 & 3.99 \\
\hline
\end{tabular}

The study involved (8) hypothesis, in order to find out the impact of (LS) on (IE) in UAE with public organizations as shown on the model of study. The hypotheses testing assume that there is a significant difference between the population mean and the sample mean. That means all hypotheses alleged that the independent variables at least one of them had a linear relationship versus (IE) dependent variable. The output of T-test that the main hypothesis (LS->EI), and other sub-hypotheses; were shown a mean difference respectively $3.696,3.837,3.922,3.829,3.766,3.444,3.823$, and 3.891. While the t-statistic respectively are 77.160, 74.309, $81.855,63.876,86.241,46.138,58.780$, and 72.905 through all variable shows Sig. (2-tailed) which means P-value were (0.00). Hence, it indicates the significant contribution to the model. Since all hypotheses are not bigger than (0.05), the researcher fails to reject any hypotheses. That is the One-Sample T-test has insufficient evidence (Ross \& Willson 2017). Moreover, the study has shown the sufficient sample size of (329), and it indicates to enough valid data were collected. Therefore, the researcher has put the output of model results based on models of Regression, Coefficients ${ }^{\mathrm{a}}$, and ANOVA Residual, the following model has investigated (Karam, 2016).

\section{Findings and Discussion}

This study examined the effect of leadership styles (LS) on Institutional excellence (EI) in UAE, the leadership styles longer-term maintenance of essential human improvement, and certain statistic factors. To look at these connections, think about inquiries that were claimed by present study. Hence, both female and male representatives were to some degree more profoundly spoke to in the example than the general four-year certification populace. To achieve study objectives, the (7) leadership styles of UAE, whose administrations lasted for at least one consecutive year or a current manager, and the excellent performance of the respective administrations were assessed by analyzing secondary data. Three categories of data were analyzed including demographic, leadership and institutional excellence practices indicators. Based on the findings of this research, one might suggest that the leadership styles and certain demographic characteristics of UAE managers might have contributed to the institutional excellence performances of their respective administrations and therefore.

The findings also suggest possible relationships between these leadership characteristics and the relative originations excellence during the administrations of managers. More specifically, the findings seem to suggest that the administrations of the managers characterized as transformational and or servant leaders were more likely to achieve originations excellence expansion than those characterized as seven (LS). Transformational and servant leadership, have become the dominant framework for appreciating leadership in the postmodern social sciences.

Based on study question: What is the relationship, if any, between the (LS) and (EI); "How and to what extent do leadership and other factors influence success in public organization. Initial analysis indicated a statistically significant, positive relationship existed between an employee's perception of Autocratic, Bureaucratic, Democratic, Charismatic, Situational, Transactional, Transformational leadership styles by his or her leader and the (EI). The relationship between these variables was examined using multiple linear Regressions. Respondents' perception of the manager's leadership style was measured using the (7) leadership styles subscale scores while attitude toward organizations development which was measured by the respondent's score on the Questionnaire. The result of regression shown a significant relationship and affect between a manager's leadership style at public organization and (EI) with $\left(\mathrm{R}=0.845 / \mathrm{R}^{2}=0.714\right)$. The solid and measurably huge relapse between (LS) 
was additionally noted and was analyzed further as a major aspect of an investigation factor. Workers were happier with their association encounter when pioneers utilized a transformational (LS) in the association; value-based authority practices likewise brought about more prominent representative's fulfillment when contrasted with different styles practices. Hence, the study was satisfied to develop a model of (LS) on (IE) and the result was a shred of far evidence to test empirically impact of leadership styles and other factors on (IE).

\section{References}

AbduRazak, L. F., Mawdieh, R. S. A., Karam, A. A., Aljaafreh, A. Y., \& Al-Azzaw, M. E. (2019). Determining the Challenges Faced by Syrian Refugees Students at Jordanian Camps According to Their Perspective: A Case of Universities Role to Supporting. Modern Applied Science, 13(8). https://doi.org/10.5539/mas.v13n8p176

Agarwal, A., \& Vrat, P. (2015). A TISM based bionic model of organizational excellence. Global Journal of Flexible Systems Management, 16(4), 361-376. https://doi.org/10.1007/s40171-015-0107-z

Ahn, J., Lee, S., \& Yun, S. (2018). Leaders' core self-evaluation, ethical leadership, and employees' job performance: The moderating role of employees' exchange ideology. Journal of Business Ethics, 148(2), 457-470. https://doi.org/10.1007/s10551-016-3030-0

Aithal, P. S. (2015). How an effective leadership and governance supports to achieve institutional vision, mission and objectives. International Journal of Multidisciplinary Research and Development, 2(5), 154-161.

Al Khajeh, E. H. (2018). Impact of leadership styles on organizational performance. Journal of Human Resources Management Research, 1-10. https://doi.org/10.5171/2018.322892

Al Shobaki, M. J., \& Abu-Naser, S. S. (2016). The Dimensions of Organizational Excellence in the Palestinian Higher Education Institutions from the Perspective of the Students.

Ali, A. A. L. (2012). The Impact of Human Resources Management on Establishing Established Excellence: An Applied Study on the Sudanese Telecom Company (dissertation).

Amit, R., Ding, Y., Villalonga, B., \& Zhang, H. (2015). The role of institutional development in the prevalence and performance of entrepreneur and family-controlled firms. Journal of Corporate Finance, 31, 284-305. https://doi.org/10.1016/j.jcorpfin.2015.01.001

Anderson, M. H., \& Sun, P. Y. (2017). Reviewing leadership styles: Overlaps and the need for a new 'fullrange'theory. International Journal of Management Reviews, 19(1), 76-96. https://doi.org/10.1111/ijmr.12082

Antonakis, J., \& Day, D. V. (Eds.). (2017). The nature of leadership. Sage publications.

Bekker, M. C. (2015). Project Governance-the definition and leadership dilemma. Procedia-Social and Behavioral Sciences, 194, 33-43. https://doi.org/10.1016/j.sbspro.2015.06.117

Bottoni, G. (2018). A multilevel measurement model of social cohesion. Social Indicators Research, 136(3), 835-857. https://doi.org/10.1007/s11205-016-1470-7

Carayannis, E. G., Grigoroudis, E., Del Giudice, M., Della Peruta, M. R., \& Sindakis, S. (2017). An exploration of contemporary organizational artifacts and routines in a sustainable excellence context. Journal of Knowledge Management. https://doi.org/10.1108/JKM-10-2015-0366

Chaluvadi, N. S. S. L. (2015). Differences in leadership styles between genders: outcomes and effectiveness of women in leadership roles.

Christensen, T., Lægreid, P., \& Rovik, K. A. (2020). Organization theory and the public sector: Instrument, culture and myth. Routledge. https://doi.org/10.4324/9780367855772

Cunningham, J., Salomone, J., \& Wielgus, N. (2015). Project Management Leadership Style: A Team Member Perspective. International Journal of Global Business, 8(2).

Cypress, B. S. (2017). Rigor or reliability and validity in qualitative research: Perspectives, strategies, reconceptualization, and recommendations. Dimensions of Critical Care Nursing, 36(4), 253-263. https://doi.org/10.1097/DCC.0000000000000253

Elrehail, H. (2018). The relationship among leadership, innovation and knowledge sharing: A guidance for analysis. Data in brief, 19, 128-133. https://doi.org/10.1016/j.dib.2018.04.138

Elrehail, H., Emeagwali, O. L., Alsaad, A., \& Alzghoul, A. (2018). The impact of transformational and authentic leadership on innovation in higher education: the contingent role of knowledge sharing. Telematics and 
Informatics, 35(1), 55-67. https://doi.org/10.1016/j.tele.2017.09.018

Fiaz, M., Su, Q., \& Saqib, A. (2017). Leadership styles and employees' motivation: Perspective from an emerging economy. The Journal of Developing Areas, 51(4), 143-156. https://doi.org/10.1353/jda.2017.0093

Fletcher, J. K. (2017). Leadership, power, and positive relationships. In Exploring positive relationships at work (pp. 347-372). Psychology Press. https://doi.org/10.4324/9781315094199-23

Gandolfi, F., \& Stone, S. (2017). The emergence of leadership styles: A clarified categorization. Revista De Management Comparat International, 18(1), 18.

Gentry, W. A., Cullen, K. L., \& Altman, D. G. (2016). The irony of integrity: A study of the character strengths of leaders. Greensboro, NC: Center for Creative Leadership.

Gray, D. E. (2019). Doing research in the business world. Sage Publications Limited.

Hassan, A. M. H. (2010). Human Resources Management Practices and their Impact on Achieving Organizational Excellence in Zain Kuwait Cellular Communications Company (dissertation).

Holten, A. L., \& Brenner, S. O. (2015). Leadership style and the process of organizational change. Leadership \& Organization Development Journal. https://doi.org/10.1108/LODJ-11-2012-0155

Jian, G., \& Fairhurst, G. T. (2017). Leadership in organizations. The international encyclopedia of organizational communication, 1-20. https://doi.org/10.1002/9781118955567.wbieoc124

Jundt, D. K., Shoss, M. K., \& Huang, J. L. (2015). Individual adaptive performance in organizations: A review. Journal of Organizational Behavior, 36(S1), S53-S71. https://doi.org/10.1002/job.1955

Karam, A. A. (2016). An Investigation of Marketing Crisis, and Outcomes influence on Buyer Behavior. Business Research Review, 2(1), 51-72.

Karam, A. A. (2019). The Impact of Training and Development on Different Cultural Employees Performance through Interaction Employees Motivation in Erbil Public and Private Banks. Social Sciences, 10(1). https://doi.org/10.2478/mjss-2019-0017

Karam, A. A., \& Kitana, A. F. (2018). The Impact of Social Media on Human Resource Management Scope Activities in Al-Futtaim and Al-Etihad Group UAE. International Business Research, 11(12). https://doi.org/10.5539/ibr.v11n12p145

Karam, A. A., \& Saydam, S. (2015). An Analysis Study of Improving Brand Awareness and Its Impact on Consumer Behavior Via Media in North Cyprus (A Case Study of Fast Food Restaurants). International Journal of Business and Social Science, 6(1).

Karam, A. A., Hamo, R. H., Rashid, H. M., Jarjes, D. A., Mohammed, C. S., \& Obaid, S. H. (2018).The Effect of Marketing Strategy Implementation on Organization Performance as a Private Business: Case of Cihan University Duhok Camps KRG-Iraq. International Journal of Business Management and Economic Research, 9(3), 1281-1295.

Karkoulian, S. (2015). The reign of leadership \& power in just organizations. https://doi.org/10.7903/cmr.12051

Kim, T. K. (2017). Understanding one-way ANOVA using conceptual figures. Korean journal of anesthesiology, 70(1), 22. https://doi.org/10.4097/kjae.2017.70.1.22

Kitana, A. F. (2019). Transformational and Transactional Leadership Styles on Organisational Change in the United Arab Emirates. Indian-Pacific Journal of Accounting and Finance, 3(3), 27-37.

Kitana, A. F., \& Karam, A. A. (2019). Career Development among Entry-Level Employees: A Case Study on Employee's in United Arab Emirates. Modern Applied Science, 13(5). https://doi.org/10.5539/mas.v13n5p13

Kitana, A., \& Karam, A. A. (2017). The relationship between work environment into women's career development and job satisfaction in the United Arab Emirates: A large scale sampling. International Journal of Business and Management Invention, 6, 22-28.

Kok, S. K., \& McDonald, C. (2017). Underpinning excellence in higher education-an investigation into the leadership, governance and management behaviours of high-performing academic departments. Studies in Higher Education, 42(2), 210-231. https://doi.org/10.1080/03075079.2015.1036849

Kumar, R. (2019). Research methodology: A step-by-step guide for beginners. Sage Publications Limited. 
Lewis, D. C., Schneider, S. K., \& Jacoby, W. G. (2015). Institutional characteristics and state policy priorities: The impact of legislatures and governors. State Politics \& Policy Quarterly, 15(4), 447-475. https://doi.org/10.1177/1532440015586315

Mohamed, M. S., Khalifa, G. S., Nusari, M., Ameen, A., Al-Shibami, A. H., \& Abu-Elhassan, A. E. (2018). Effect of Organizational Excellence and Employee Performance on Organizational Productivity Within Healthcare Sector in the UAE. Journal of Engineering and Applied Sciences, 13(15), 6199-6210. https://doi.org/10.36478/jeasci.2018.6199.6210

Mouton, N. (2019). A literary perspective on the limits of leadership: Tolstoy's critique of the great man theory. Leadership, 15(1), 81-102. https://doi.org/10.1177/1742715017738823

Muralidharan, K. (2015). Six Sigma for organizational excellence. Springer Proceedings of the Institution of Mechanical Engineers, 203(B1), 43-50. https://doi.org/10.1007/978-81-322-2325-2

Naser, S. S. A., \& Al Shobaki, M. J. (2017). Organizational Excellence and the Extent of Its Clarity in the Palestinian Universities from the Perspective of Academic Staff.

Onsardi, O., \& Arkat, F. (2020). The Effect Of Transformational Leadership Style And Work Spirit On Employee Performance At Raffles City Hotel Bengkulu Indonesia (No. gtw9z). Center for Open Science. https://doi.org/10.31219/osf.io/gtw9z

Overall, J. (2015). A conceptual framework of innovation and performance: The importance of leadership, relationship quality, and knowledge management. Academy of Entrepreneurship Journal, 21(2), 41.

Pinar, M., \& Girard, T. (2008). Investigating the impact of organizational excellence and leadership on business performance: An exploratory study of Turkish firms. SAM Advanced Management Journal, 73(1), 29.

Ross, A., \& Willson, V. L. (2017). One-sample T-test. In Basic and Advanced Statistical Tests (pp. 9-12). Brill Sense. https://doi.org/10.1007/978-94-6351-086-8_4

Sahoo, C. K., \& Sahu, G. (2009). Effective employee engagement: The mantra of achieving organizational excellence. Management and labour studies, 34(1), 73-84. https://doi.org/10.1177/0258042X0903400105

Sendjaya, S. (2016). Personal and organizational excellence through servant leadership. Springer International Pu. https://doi.org/10.1007/978-3-319-16196-9

Silhavy, R., Silhavy, P., \& Prokopova, Z. (2017). Analysis and selection of a regression model for the Use Case Points method using a stepwise approach. Journal of Systems and Software, 125, 1-14. https://doi.org/10.1016/j.jss.2016.11.029

Sleimi, M. T., Karam, A. A., \& Qubbaj, I. S. (2018). The impact of e-banking services quality on customers satisfaction moderated by customer trust: Survey on arab bank in Amman. Jordan. Journal of Al-Quds Open University for Administrative \& Economic Research, 3(9). https://doi.org/10.33977/1760-003-009-016

Smith, W. K., Lewis, M. W., \& Tushman, M. L. (2016). Both/and” leadership. Harvard Business Review, 94(5), 62-70.

Taamneh, A. (2015). The impact of practicing interactional justice on employees organizational citizenship behavior (OCB) in the Jordanian Ministry of Justice. Graduate School of Business, Girne American University, Turkey.

Taamneh, A., Alsaad, A. K., \& Elrehail, H. (2018). HRM practices and the multifaceted nature of organization performance. EuroMed Journal of Business. https://doi.org/10.1108/EMJB-02-2018-0010

Tempel, E. R., Seiler, T. L., \& Burlingame, D. F. (2016). Achieving excellence in fundraising. John Wiley \& Sons.

Tortorella, G., \& Fogliatto, F. (2017). Implementation of lean manufacturing and situational leadership styles. Leadership \& Organization Development Journal. https://doi.org/10.1108/LODJ-07-2016-0165

Valeriano, B., Jensen, B. M., \& Maness, R. C. (2018). Cyber Strategy: The Evolving Character of Power and Coercion. Oxford University Press. https://doi.org/10.1093/oso/9780190618094.001.0001

Weber, M. (2017). Methodology of social sciences. Routledge. https://doi.org/10.4324/9781315124445

Wildavsky, A. (2018). A cultural theory of leadership. In Cultural Analysis (pp. 253-282). Routledge. https://doi.org/10.4324/9780203794234

Yahaya, R., \& Ebrahim, F. (2016). Leadership styles and organizational commitment: literature review. Journal 
of Management Development. https://doi.org/10.1108/JMD-01-2015-0004

Zhang, D. (2017). A coefficient of determination for generalized linear models. The American Statistician, 71(4), 310-316. https://doi.org/10.1080/00031305.2016.1256839

\section{Copyrights}

Copyright for this article is retained by the author(s), with first publication rights granted to the journal.

This is an open-access article distributed under the terms and conditions of the Creative Commons Attribution license (http://creativecommons.org/licenses/by/4.0/). 